Tropical Journal of Pharmaceutical Research May 2020; 19 (5): 1073-1080

ISSN: $1596-5996$ (print); 1596-9827 (electronic)

(C) Pharmacotherapy Group, Faculty of Pharmacy, University of Benin, Benin City, 300001 Nigeria.

\title{
Cytotoxic and antioxidant potentials of ellagic acid derivatives from Conocarpus lancifolius (Combretaceae)
}

\author{
Malik Saadullah'*, Muhammad Asif ${ }^{1,2}$, Abdul Sattar ${ }^{3}$, Kanwal Rehman $^{4}$, Shahid \\ Shah $^{1}$, Mohammad Saleem ${ }^{5}$, Ajmal Shah', Muhammad Wajid ${ }^{6}$, Akhtar Rasool $^{1}$, \\ Muhammad Uzair ${ }^{7}$, Samina Afzal ${ }^{7}$, Khurram Afzal ${ }^{7}$ \\ ${ }^{1}$ Faculty of Pharmaceutical Sciences Government College University Faisalabad, ${ }^{2}$ Department of Pharmacy, The Islamia \\ University of Bahawalpur, ${ }^{3}$ College of Agriculture Bahadur Campus, Layyah Bahauddin Zakariya University, Multan, ${ }^{4}$ Institute of \\ Pharmacy, Physiology and Pharmacology, University of Agriculture, Faisalabad, ${ }^{5}$ University College of Pharmacy, Universty of \\ the Punjab, Institute of Pharmacy Gulab Devi Educational Complex, Ferozepur Road, Lahore, ${ }^{7}$ Faculty of Pharmacy, Bahaudin \\ Zakariya University, Multan, Pakistan
}

*For correspondence: Email: maliksaadullah@gcuf.edu.pk

\begin{abstract}
Purpose: Isolation, characterisation and structure elucidation of compounds obtained from Conocarpus lancifolius and screening of their pharmacological effects in vitro.

Methods: After collection, authentication and extraction from whole C. lancifolius plants, screening for secondary metabolites, thin-layer chromatography and subsequent open column chromatography were performed for phytochemical analysis and subsequent purification of the compounds. The chemical structures of the isolated compounds were elucidated using spectroscopic (UV-visible, infrared and mass) spectroscopy, and nuclear magnetic resonance $\left({ }^{1} \mathrm{H}-\mathrm{NMR},{ }^{13} \mathrm{C}-\mathrm{NMR}\right.$ including BB, DEPT-135, 90 and two-dimensional correlation techniques, including HMBC and HSQC). The cytotoxic and antioxidant potentials of extracts and compounds obtained from $C$. lancifolius were evaluated using in vitro models. Results: Two ellagic acid derivatives, 2,3,8-tri-o-methylellagic acid (A) and 3-O-methylellagic acid 4-O$\beta$-D-glucopyranoside $(B)$, were isolated. Both compounds $(A$ and $B)$ were cytotoxic in a variety of cancer cell lines, including murine lymphocytic leukaemia $\left(P-388\right.$, half-maximal inhibitory concentration $\left(I C_{50}\right)=$ 3.60 and $2.40 \mu \mathrm{g} / \mathrm{mL}$, respectively), human colon cancer $\left(\mathrm{Col}-2, \quad I C_{50}=0.76\right.$ and $0.92 \mu \mathrm{g} / \mathrm{mL}$, respectively) and human breast cancer (MCF-7, $I C_{50}=0.65$ and $0.54 \mu \mathrm{g} / \mathrm{mL}$, respectively). Moreover, both compounds showed significant antioxidant potential in vitro.

Conclusion: C. lancifolius extract and isolated ellagic acid derivatives (compounds $A$ and $B$ ) possess cytotoxic and antioxidant properties. These findings suggest that $C$. lancifolius contains bioactive compounds that can be potentially developed as natural cytotoxic and antioxidant compounds.
\end{abstract}

Keywords: Conocarpus lancifolius, Ellagic acid, Combretaceae, Cytotoxic activity, Antioxidant

This is an Open Access article that uses a fund-ing model which does not charge readers or their institutions for access and distributed under the terms of the Creative Commons Attribution License (http://creativecommons.org/licenses/by/4.0) and the Budapest Open Access Initiative (http://www.budapestopenaccessinitiative.org/read), which permit unrestricted use, distribution, and reproduction in any medium, provided the original work is properly credited.

Tropical Journal of Pharmaceutical Research is indexed by Science Citation Index (SciSearch), Scopus, International Pharmaceutical Abstract, Chemical Abstracts, Embase, Index Copernicus, EBSCO, African Index Medicus, JournalSeek, Journal Citation Reports/Science Edition, Directory of Open Access Journals (DOAJ), African Journal Online, Bioline International, Open-J-Gate and Pharmacy Abstracts

\section{INTRODUCTION}

Combretaceae is a medicinally important flowering plant family that comprises 20 genera.
Of these genera, Terminalia and Combretum have been extensively studied for their chemical composition and biological attributes. Combretaceae includes ornamental trees with a 
high-tolerance to heat and semi-arid conditions; they are usually grown in Saudi Arabia [1]. The leaves are simple and complete, spirally arranged or alternate having glands and domatia. The flowers are bisexual or male, 4-5-merous, actinomorphic, in axillary spikes or racemes. The genus Conocarpus consists of only two species, namely Conocarpus erectus and Conocarpus lancifolius [2]. C. lancifolius, an ornamental tree, is native to coastal and riverine areas of East Africa [3]. This fast-growing tree thrives in sandy soils and semi-arid conditions. Mature leaves are glossy in appearance with relatively few trichomes on both surfaces and contain two cavities or secretory ducts that secrete epicuticular waxes, polyphenols and polysaccharides [4]. A methanol extract of the aerial part of $C$. lancifolius has antidiabetic potential via suppression of gluconeogenesis in an alloxan-induced diabetes rabbit model [5]. The methanol extract of $C$. lancifolius fruit demonstrates a noticeable cytotoxic effect against MRC-5 cells, as well as antiprotozoal activity [6]. The alkaloidal extract of $C$. lancifolius leaves exhibits antibacterial activity [7]. The methanol extract of $C$. lancifolius shows moderate antibacterial and low antifungal activities [7]. Antioxidant, phytotoxic and antiurease activities, and total phenolic and flavonoid contents of $C$. lancifolius have already been reported by our research group [8].

\section{EXPERIMENTAL}

Plant material was collected from different areas Lahore (Pakistan) in August 2012. After authentication by Professor Dr Altaf Ahmad Dasti, Institute of Pure and Applied Biology, Bahauddin Zakariya University, Multan, Pakistan, a voucher specimen (no. WCL-291) was allotted and the sample was deposited in the institute's herbarium.

\section{Materials}

Materials used for extraction, chemical characterisation and isolation purposes were polar and non-polar solvents, including chloroform (C), dichloromethane (DCM), methyl alcohol (ME), ethyl acetate (EA), n-hexane (nHex) and vanillin. M TLC plates (Merck Silica gel $60 \mathrm{~F}_{254} ; 20 \times 20 \mathrm{~cm}$ ) were used for the separation of fractions.

\section{Extraction}

Whole C. lancifolius plants were dried and ground to form a coarse powder using a grinder. The coarse powder was subjected to sequential DCM and ME extraction by the successive maceration method. Soaked material was filtered through filter paper and the collected filtrates were concentrated using a rotary evaporator. The resultant extracts were labelled as CLD and CLM and were subjected to cytotoxic screening. Based on the half maximal inhibitory concentration $\left(\mathrm{IC}_{50}\right)$, the CLM was selected for further fractionation and isolation of bioactive compounds.

\section{Screening for secondary metabolites}

The powdered plant material was weighed, and different qualitative tests for alkaloids, cardiac glycosides, anthraquinones, saponins, tannins and triterpenoids were performed following standard protocols.

\section{Purification of compounds A and B}

The CLM (10 g) was fractionated by step-wise elution using column chromatographic techniques. The stationary phase was silica gel $60(40-63 \mu \mathrm{m})$ and the mobile phases was a mixture of $\mathrm{C}, \mathrm{ME}$ and water. This protocol resulted in the collection of four fractions (CLM14). CLM-2 (5.2 g) was further fractionated through column chromatography using the mobile phase with an 80:20:2 ratio of C:ME:water and silica gel 60 with a pore size of $40-63 \mu \mathrm{m}$ as the stationary phase. This procedure resulted in the collection of six sub-fractions (CLM-2a to CLM-2f). CLM-2b was collected as a pure compound A (42 mg). The CLM-2c (720 mg) sub-fraction was further fractionated. Seven subfractions were collected, out of which CLM-2c7 was a pure compound $\mathbf{B}$ (28 mg).

\section{Evaluation of cytotoxic potential}

The cytotoxic effect of both extracts (CLD and CLM) and isolated compounds ( $A$ and $B$ ) were studied using the in vitro sulforhodamine $B$ (SRB) method [9]. Ellipticine and medium containing the same per cent of dimethyl sulfoxide (DMSO) were used as the positive and negative control, respectively. Extracts and isolated compounds were dissolved in DMSO to prepare stock solutions $(4 \mathrm{mg} / \mathrm{ml})$. Six different concentrations of test samples were prepared and tested in triplicate; the final DMSO concentration was 0.5\%. Cell lines (P-388, MCF-7, ASK, HEK293 and T24) were cultured in Minimum Essential Medium (MEM) containing L-glutamine and $10 \%$ foetal bovine serum (FBS). Lu-1 cells were grown in MEM with 5\% FBS. After 48- (P-388) or 72-h treatment, cells were fixed with trichloroacetic acid (10\%) and stained with sulforhodamine $B(0.4 \%$ in $1 \%$ acetic acid). Unbound dye was removed by washing, while 
bound and dried stain was solubilised with 10 $\mathrm{mM}$ Trizma base. The absorbance was measured at $510 \mathrm{~nm}$ using a BMG FLUostar OPTIMA plate reader. The data are expressed as the median effective dose $\left(E_{50}\right) \pm$ standard error of the mean (SEM) of three independent experiments $(n=3)$.

\section{Evaluation of antioxidant activity}

Two in vitro methods, viz, 2,2-diphenyl-1picrylhydrazyl (DPPH) and nitric oxide (NO) free radical scavenging assays were employed to screen the antioxidant potential of the test samples.

\section{DPPH free radical scavenging assay}

In brief, $100 \mu \mathrm{L}$ of DPPH solution (200 $\mu \mathrm{M}$ in methanol) was mixed with $100 \mu \mathrm{L}$ of test solution $(10 \mathrm{mg} / \mathrm{ml} \mathrm{CLM}$ or $10 \mu \mathrm{M}$ compound A or B). The reaction was allowed to proceed for $30 \mathrm{~min}$ at room temperature in the dark. The absorbance of the remaining DPPH free radical was measured using a multi-plate reader (Spectra Max 340) at $517 \mathrm{~nm}$. The per cent radical scavenging activity (\%RSA) was determined by comparison with a DMSO-containing control. The $\mathrm{IC}_{50}$ values of the compounds were calculated using EZ-Fit Enzyme kinetics software (Perrella Scientific Inc. Amherst, MA, USA). Ascorbic acid was used as a reference standard [10].

\section{NO scavenging assay}

In brief, $10 \mathrm{mM}$ of sodium nitroprusside in phosphate-buffered saline was mixed with different concentrations of CLM or compounds $A$ and $B$ and incubated at $300^{\circ} \mathrm{C}$ for $2 \mathrm{~h}$. The same reaction mixture without extract, but containing an equivalent amount of ethanol, was used as the control. After the incubation period, $500 \mu \mathrm{L}$ of Griess reagent (1\% sulfanilamide, $2 \% \mathrm{H}_{3} \mathrm{PO}_{4}$ and $0.1 \% \mathrm{~N}$-(1-naphthyl) ethylenediamine dihydrochloride) was added to the reaction mixture. The absorbance of the chromophore formed during diazotisation of nitrite with sulfanilamide and subsequent coupling with naphthyl ethylenediamine dihydrochloride was measured instantly at $550 \mathrm{~nm}$ using a plate reader. The inhibition of nitrite formation by CLM, compound $A$ or $B$ and quercetin (standard) were calculated relative to the control. The $\mathrm{IC}_{50}$ values were calculated using the EZ-Fit enzyme kinetics software programme [11].

\section{Statistical analysis}

The results are presented as mean \pm SEM. GraphPad Prism software was used to test differences between groups using one-way analysis of variance (ANOVA). $p<0.05$ was considered significant.

\section{RESULTS}

\section{Extraction}

Sequential extraction of C. lancifolius with DCM and ME resulted in the collection of two extracts, which were labelled as CLD and CLM. The per cent yields of CLD and CLM were $1.33 \%$ and $2.11 \%$, respectively.

\section{Screening of secondary metabolites}

Data of qualitative screening of CLM showed the presence of alkaloids, saponins, steroids and triterpenoids, flavonoids, cardiac glycosides, anthraquinones and tannins.

\section{Physical and spectroscopic characteristics of 2,3,8-tri-O-methyl ellagic acid (compound A)}

The spectra details for compound A were: Infrared (IR, KBr) vmax: 1723, 3512, 2934, 1661, 1615 and $15761 \mathrm{~cm}^{-1}$; Ultraviolet (UV) Amax: 205.5 and $243 \mathrm{~nm},[\alpha]_{\mathrm{D}}{ }^{25}$ : + 40 (0.021); electron ionisation-mass spectrometry (El-MS), m/z: 76.0, $102.8,112,145.1,241.1,257.9,313.2,328.2$ and 334.0; high-resolution (HR)-El-MS: 344.05 (for $\left.\mathrm{C}_{17} \mathrm{H}_{12} \mathrm{O}_{8}, 344.05\right) ;{ }^{1} \mathrm{H}$ and ${ }^{13} \mathrm{C}$ nuclear magnetic resonance (NMR). The structure of compound $A$ is shown in Figure 1.

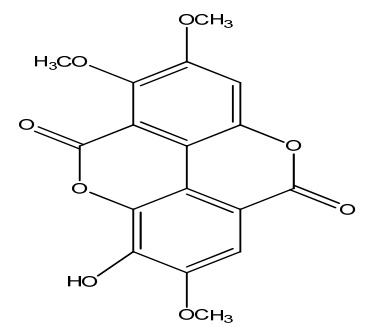

Figure 1: Structure of 2, 3, 8 tri-O-methyl ellagic acid (Compound A)

Compound A was collected as a pale yellowish solid. The ultraviolet spectrum showed absorption at 206 and $243 \mathrm{~nm}$. The IR spectrum showed absorption bands at 3510, 2844, 1561, 1515 and $1474 \mathrm{~cm}^{-1}$. The HR-El-MS provided an ion peak for a molecule at 344 , elucidating the formula as $\mathrm{C}_{17} \mathrm{H}_{1} \mathrm{O}_{8}$, (for $\mathrm{C}_{17} \mathrm{H}_{2} \mathrm{O}_{8}, 344.5$ ). The fragmentation pattern by retro-Diels-Alder reaction in El-MS showed a peak at $m / z$ 196, which indicated the presence of two methoxyl groups in ring $B$ and one methoxyl and one hydroxyl group in ring $\mathrm{A}$. The ${ }^{1} \mathrm{H}-\mathrm{NMR}$ spectrum showed aromatic protons at $\delta 7.46(\mathrm{~s}, 1 \mathrm{H})$ and 
$8.16(\mathrm{~s}, 1 \mathrm{H})$, which are characteristic of the ellagic acid skeleton, together with three methoxy protons at $\delta 3.92,4.02$ and 4.12 (s, 9H). Taken together, these characteristics indicated a trimethoxy ellagic acid.

The proton NMR spectrum of compound $\mathbf{A}$ showed three methoxy group signals in the downfield region. Aromatic protons appeared at $\delta$ $6.36(1 \mathrm{H}$, singlet, $\mathrm{H}-8)$ with a disubstituted (ABX system) pattern. The signals at $\delta 6.95(1 \mathrm{H}, \mathrm{d}$, with $J=4.2 \mathrm{~Hz}, \mathrm{H}-5$ ) and $\delta 11.47$ showed hydroxyl group chelation at the $\mathrm{H}-5$ position.

The broadband and depth $\left({ }^{13} \mathrm{C}-\mathrm{NMR}\right)$ spectra of compound $\mathbf{A}$ gave 17 signals, data that indicate the presence of three methyl, two methine and 12 for quaternary carbons. The positions of three methoxy groups at $\mathrm{C}-3, \mathrm{C}-2$ and $\mathrm{C}-8$ were determined based on ${ }^{3} \mathrm{~J}$ HMBC correlations. All spectral, literature and physical data confirmed the identification of compound $\mathbf{A}$ as 2,3,8-tri-Omethylellagic acid. It was previously identified from the bark of Irvingia gabonensis [12]. See Table 1.

Physical and spectroscopic characteristics of 3-O-methylellagic acid 4-O- $\beta$ D-glucopyranoside (compound B)

As stated in Table 3, the spectra details for compound B were: UV $\lambda_{\max }: 213,222$ and 229 $\mathrm{nm}, \quad[\alpha]_{\mathrm{D}}{ }^{25}:-19.3^{\circ}$ (c 0.022$)$, IR (KBr) vmax: $3355.9(\mathrm{O}-\mathrm{H}), 1645(\mathrm{C}=\mathrm{C}), 1728(\mathrm{C}=\mathrm{O})$ and $2923 \mathrm{~cm}^{-1}$; El-MS: 477 (32), 268.5 (15), 226 (23), 194 (11) and 168.5 (12); HR-El-MS: 477.06 (for $\left.\mathrm{C}_{21} \mathrm{H}_{18} \mathrm{O}_{3}, 477.0669\right) ;{ }^{1} \mathrm{H}$ and ${ }^{13} \mathrm{C}$ NMR.

Compound B was collected as an amorphous powder. The UV spectrum showed absorption at
213, 222 and $229 \mathrm{~nm}$. The IR spectrum showed absorption at $3355.9 \mathrm{~cm}^{-1}$ and $1645 \mathrm{~cm}^{-1}$, indicative of a hydroxyl group and $\mathrm{C}=\mathrm{C}$, respectively. $\mathrm{Sp}^{3} \mathrm{C}-\mathrm{H}$ stretching was observed at $2923.9 \mathrm{~cm}^{-1}$. Absorption at $1728.1 \mathrm{~cm}^{-1}$ indicated the presence of a carbonyl group.

The ${ }^{1} \mathrm{H}$ NMR spectrum of compound $\mathbf{B}$ indicated the existence of aromaticity in a molecule with proton resonance at $\delta 7.58(1 \mathrm{H}, \mathrm{d}$ having $J=4.2$, $\mathrm{Hz}), 7.62(1 \mathrm{H}, \mathrm{dd}, J=3.1,1.2, \mathrm{~Hz})$ and $7.52(1 \mathrm{H}$, $\mathrm{dd}, J=0.4,2.6, \mathrm{~Hz})$. The signals at $\delta 7.43(1 \mathrm{H}$, singlet) specified a phenolic proton. The signals at $\delta 4.21$ ( $d$ having $J=2.3 \mathrm{~Hz}$ ) indicated the presence of a lactone moiety."<smiles>COc1cc2c(=O)oc3c(O)c(O)cc4c(=O)oc(c1O)c2c34</smiles>

Figure 2: Structure of 3-O-methyl ellagic acid 4-O- $\beta$ D-glucopyranoside (Compound B)

The broadband and depth $\left({ }^{13} \mathrm{C}-\mathrm{NMR}\right)$ spectrum of compound $\mathbf{B}$ revealed 21 carbon signals: one methylene, seven methine and 12 quaternary carbon signals.

Table 1: ${ }^{13} \mathrm{C}-\mathrm{NMR}(125 \mathrm{MHz})$ and ${ }^{1} \mathrm{H}-\mathrm{NMR}(500 \mathrm{MHz})$ spectral data of 2, 3, 8 tri-O-methyl ellagic acid

\begin{tabular}{|c|c|c|c|c|}
\hline $\begin{array}{l}\text { Carbon } \\
\text { no. }\end{array}$ & $\begin{array}{c}\text { Multiplicity } \\
\text { DEPT }\end{array}$ & ${ }^{13} \mathrm{C}-\mathrm{NMR}(\overline{\mathrm{C}})$ & 1H-NMR & J. Value \\
\hline$C-1$ & $\mathrm{C}$ & 109.50 & - & - \\
\hline$C-2$ & $\mathrm{C}$ & 138.20 & - & - \\
\hline$C-3$ & $\mathrm{C}$ & 138.54 & - & - \\
\hline$C-4$ & $\mathrm{C}$ & 146.35 & - & - \\
\hline$C-5$ & $\mathrm{CH}$ & 108.20 & $6.80 \mathrm{~s}$ & $(\mathrm{~J}=2.5, \mathrm{~Hz}, \mathrm{H}-1)$ \\
\hline$C-6$ & $\mathrm{C}$ & 109.40 & - & (c) \\
\hline$C-7$ & $\mathrm{C}$ & 109.91 & - & \\
\hline$C-1$ & $\mathrm{C}$ & 113.55 & - & - \\
\hline$C-2$ & $\mathrm{C}$ & 139.35 & - & - \\
\hline$C-3$, & $\mathrm{C}$ & 139.92 & & \\
\hline$C-4$ & $\mathrm{C}$ & 148.72 & - & - \\
\hline$C-5$ & $\mathrm{CH}$ & 105.55 & $6.92 \mathrm{~d}$ & $(\mathrm{~J}=3.1,2.4 \mathrm{~Hz}, \mathrm{H}-2)$ \\
\hline$C-6$ & $\mathrm{C}$ & 110.22 & - & $(0-0.1,2.411<, 11-2)$ \\
\hline$C-7$ & $\mathrm{C}$ & 152.90 & - & - \\
\hline $\begin{array}{l}C-15 \\
C-16\end{array}$ & $\begin{array}{l}\mathrm{OCH}_{3} \\
\mathrm{OCH}_{3}\end{array}$ & $\begin{array}{l}54.45 \\
59.20\end{array}$ & $\begin{array}{c}3.352 \mathrm{~s} \\
4.87 \mathrm{~s}\end{array}$ & $\begin{array}{l}(\mathrm{J}=4.2 \mathrm{~Hz}) \\
(\mathrm{J}=5.5 \mathrm{~Hz})\end{array}$ \\
\hline
\end{tabular}


The $\delta 169.0$ signal singlet representing the downfield region indicated a carbonyl carbon in the molecule. The signals at $\delta 71.6,69.0$ specified lactone carbons. The signals at $\delta$ 129.7, 128.9, 130.8 and 130.9 showed aromaticity in the molecule. All spectral, literature and physical data confirmed the identification of compound B as 3-O-methyl ellagic acid 4-O- $\beta-D-$ glucopyranoside. This molecule was previously isolated from Anisophyllea dichostyla root bark [13].

The structures of compounds $\mathrm{A}$ and $\mathrm{B}$ were assigned from ${ }^{1} \mathrm{H}$ - and ${ }^{13} \mathrm{C}$ - NMR spectra in combination with electrospray ionisation mass spectrometry (ESI-MS) experiments and comparison with literature data of related compounds (Table 2).

\section{Cytotoxic potential}

Table 3 shows the effect of CLD and CLM extracts and isolated compounds (A and $B$ ) treatment on different cancer and normal cell lines. CLM had more cytotoxic potential compared with CLD. Compound B showed greater cytotoxic effects compared with compound $\mathrm{A}$.

\section{Antioxidant activity}

Table 4 shows the antioxidant potential of bioactive CLM and isolated compounds in two in vitro assays. CLM showed better free radical scavenging compared with the isolated compounds. Compound B showed a better free radical scavenging effect compared to compound A.

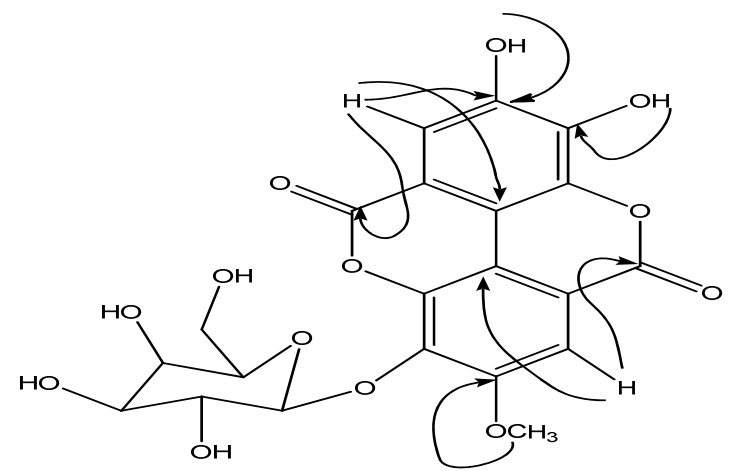

Figure 3: Important HMBC correlations of 3-O-methyl ellagic acid 4-O- $\beta$ D-glucopyranoside

\section{DISCUSSION}

The data presented in the current study are a continuation of a previous research report [8] in which it was found that extracts prepared using different parts of $C$. lancifolius contain compounds with antioxidant and cytotoxic potentials. However, the previous study reported antioxidant and cytotoxic potentials of crude extracts. Therefore, the current study was conducted to isolate compounds from $C$. lancifolius whole plant extracts following bioactivity-guided isolation methods.

Table 2: ${ }^{13} \mathrm{C}$-NMR $(125 \mathrm{MHz})$ and ${ }^{1} \mathrm{H}-\mathrm{NMR}(500 \mathrm{MHz})$ spectral data of $3-\mathrm{O}-$ methyl ellagic acid $4-\mathrm{O}-\beta$ Dglucopyranoside (Compound B)

\begin{tabular}{|c|c|c|c|c|}
\hline Carbon no. & $\begin{array}{l}\text { Multiplicity } \\
\text { DEPT }\end{array}$ & $\begin{array}{c}C^{13}-N M R \\
(\delta)\end{array}$ & Proton NMR & J. Value \\
\hline$C-1$ & C & 106.50 & - & - \\
\hline$C-2$ & $\mathrm{C}$ & 129.60 & - & - \\
\hline$C-3$ & $\mathrm{C}$ & 138.54 & - & - \\
\hline$C-4$ & C & 139.50 & - & - \\
\hline$C-5$ & $\mathrm{CH}$ & 109.20 & $6.54 \mathrm{~s}$ & $(\mathrm{~J}=4.2, \mathrm{~Hz}, \mathrm{H}-1)$ \\
\hline$C-6$ & C & 111.70 & - & - \\
\hline$C-7$ & $\mathrm{C}$ & 149.62 & - & \\
\hline$C-1^{\prime}$ & $\mathrm{C}$ & 110.52 & - & - \\
\hline$C-2^{\prime}$ & $\mathrm{C}$ & 140.24 & - & - \\
\hline$C-3^{\prime}$ & $\mathrm{C}$ & 141.32 & & \\
\hline$C-4^{\prime}$ & C & 149.82 & - & - \\
\hline$C-5^{\prime}$ & $\mathrm{CH}$ & 112.15 & $5.85 \mathrm{~d}$ & $(\mathrm{~J}=6.2,5.1 \mathrm{~Hz}, \mathrm{H}-2)$ \\
\hline$C-6^{\prime}$ & C & 112.80 & - & - \\
\hline$C-7$ & $\mathrm{C}$ & 160.20 & - & - \\
\hline C -1" & $\mathrm{CH}$ & 101.40 & $3.76 \mathrm{~d}$ & $(\mathrm{~J}=3.42, \mathrm{~Hz}, \mathrm{H}-1)$ \\
\hline C - 2" & $\mathrm{CH}$ & 69.42 & $3.32 \mathrm{~m}$ & $(\mathrm{~J}=5.10, \mathrm{~Hz}, \mathrm{H}-1)$ \\
\hline$C-3^{\prime \prime}$ & $\mathrm{CH}$ & 70.14 & $3.19 \mathrm{~m}$ & $(\mathrm{~J}=5.50, \mathrm{~Hz}, \mathrm{H}-1)$ \\
\hline$C-4 "$ & $\mathrm{CH}$ & 71.10 & $3.10 \mathrm{~m}$ & $(\mathrm{~J}=4.22, \mathrm{~Hz}, \mathrm{H}-1)$ \\
\hline$C-5^{\prime \prime}$ & $\mathrm{CH}$ & 73.22 & $2.71 \mathrm{~m}$ & $(\mathrm{~J}=4.2, \mathrm{~Hz}, \mathrm{H}-1)$ \\
\hline$C-6^{\prime \prime}$ & $\mathrm{CH}_{2}$ & 64.62 & $2.91,3.12 \mathrm{~m}$ & $(\mathrm{~J}=3.22, \mathrm{~Hz}, \mathrm{H}-2)$ \\
\hline $\mathrm{OCH}$ & - & 59.1 & $3.90 \mathrm{~s}$ & $(\mathrm{~J}=2.92, \mathrm{~Hz})$ \\
\hline
\end{tabular}


Table 3: Cytotoxicity of extracts and pure compounds from C. lancifolius

\begin{tabular}{|c|c|c|c|c|c|c|}
\hline \multirow{2}{*}{$\begin{array}{l}\text { Crude extract/ } \\
\text { Pure compound }\end{array}$} & \multicolumn{4}{|c|}{ Cytotoxicity (ED $50, \mu \mathrm{g} \mathrm{mL} \mathrm{-1)} \mathrm{Cancer} \mathrm{cells}$} & \multicolumn{2}{|c|}{ Normal cells } \\
\hline & $P-388$ & Col-2 & $\begin{array}{c}\text { MCF- } \\
7\end{array}$ & Lu-1 & ASK & Hek293 \\
\hline Dichloromethane & 8.05 & 7.45 & 1.25 & 12.70 & 11.6 & 6.74 \\
\hline Methanol & 2.07 & 1.98 & 0.3 & 5.85 & 3.25 & $<4.00$ \\
\hline $\begin{array}{l}\text { Compound } \boldsymbol{A}(2,3, \\
8 \text { tri-O-methyl } \\
\text { ellagic acid) }\end{array}$ & 3.60 & 0.76 & 0.65 & NR & 16.05 & 2.81 \\
\hline Compound B & & & & & & \\
\hline $\begin{array}{l}\text { (3-O-methyl ellagic } \\
\text { acid } 4-O-\beta \text { D- } \\
\text { glucopyranoside) }\end{array}$ & 2.40 & 0.92 & 0.54 & NR & 14.30 & 2.62 \\
\hline $\begin{array}{l}\text { Ellipticine (positive } \\
\text { control) }\end{array}$ & 0.4 & 0.51 & 0.37 & 0.23 & 0.23 & 0.58 \\
\hline
\end{tabular}

Cytotoxic assay: ED $50<20 \mu \mathrm{g} \mathrm{mL}-1$ were considered active for CLD and CLM extracts and $<4 \mu \mathrm{g} / \mathrm{mL}$ for pure compounds $(A$ and $B)$

Table 4: Antioxidant activity of methanol extract and pure compounds isolated from C. lancifolius

\begin{tabular}{|c|c|c|c|c|c|}
\hline \multirow[b]{2}{*}{ Code } & \multirow[b]{2}{*}{$\begin{array}{c}\text { Concentration } \\
\text { (mg) }\end{array}$} & \multicolumn{2}{|c|}{ DPPH assay } & \multicolumn{2}{|c|}{ NO scavenging assay } \\
\hline & & $\begin{array}{c}I_{50} \pm S E M \\
(\mu \mathrm{g} / \mathrm{mL})\end{array}$ & Inhibition (\%) & $\begin{array}{c}I_{50} \pm S E M \\
(\mu \mathrm{g} / \mathrm{mL})\end{array}$ & Inhibition (\%) \\
\hline \multirow{4}{*}{ CLM } & $0.5 \mathrm{mg}$ & & $79.30 \pm 0.75$ & \multirow{4}{*}{$39.41 \pm 0.08$} & $80.25 \pm 0.03$ \\
\hline & $0.25 \mathrm{mg}$ & $22.45 \pm 0.03$ & $78.55 \pm 0.45$ & & $64.32 \pm 0.05$ \\
\hline & $0.125 \mathrm{mg}$ & & $48.02 \pm 0.35$ & & $43.12 \pm 0.02$ \\
\hline & $0.5 \mathrm{mg}$ & & $83.37 \pm 0.29$ & & $78.15 \pm 0.03$ \\
\hline \multirow{3}{*}{ Compound A } & $0.25 \mathrm{mg}$ & $41.66 \pm 0.08$ & $65.55 \pm 0.86$ & \multirow{3}{*}{$49.04 \pm 0.08$} & $56.67 \pm 0.07$ \\
\hline & $0.125 \mathrm{mg}$ & & $42.32 \pm 0.52$ & & $33.43 \pm 0.04$ \\
\hline & $0.5 \mathrm{mg}$ & & $69.45 \pm 0.16$ & & $68.25 \pm 0.02$ \\
\hline \multirow[t]{2}{*}{ Compound B } & $0.25 \mathrm{mg}$ & $38.42 \pm 0.05$ & $62.35 \pm 0.23$ & \multirow[t]{2}{*}{$42.05 \pm 0.04$} & $54.55 \pm 0.04$ \\
\hline & $0.125 \mathrm{mg}$ & & $39.65 \pm 0.45$ & & $29.35 \pm 0.03$ \\
\hline \multirow{2}{*}{$\begin{array}{l}\text { Ascorbic acid } \\
\text { (Quercetin) }\end{array}$} & $0.5 \mathrm{mg}$ & $7.06 \pm 1.2$ & $96 \pm 0.7$ & & \\
\hline & $0.5 \mathrm{mg}$ & & & $14.4 \overline{7 \pm} \pm 0.13$ & $90.2 \overline{1} \pm 0.03$ \\
\hline
\end{tabular}

Values shown are mean \pm SEM $(n=3)$. Where CLM $=$ methanolic extract of Conocarpus lancifolius. Compound $B$ showed better antioxidant activity as compared with compound $A$

It is a well-known fact that the majority of anticancer agents available on the market today are of a natural origin [14]. However, the available cytotoxic agents have mostly limited selectivity towards cancer cells. Hence, researchers around the globe are in a continuous search to identify and isolate novel molecules that have more specific actions towards cancer cells [15]. The current study was designed to isolate bioactive compounds from the most active whole C. lancifolius plant extracts. Data from the previous study showed profound antidiabetic activity of methanolic extract in alloxan-induced diabetic rabbits [5] and antioxidant activity [8].

This study demonstrates that 2,3,8-tri-Omethylellagic acid and 3-O-methylellagic acid 4O- $\beta$-D-glucopyranoside, both of which were isolated from $C$. lancifolius, had significant antitumor properties against murine lymphocytic leukaemia $\left(P-388, I_{50}=3.60\right.$ and $2.40 \mu \mathrm{g} / \mathrm{mL}$, respectively), human colon cancer $\left(\mathrm{Col}-2, \mathrm{IC}_{50}=\right.$ 0.76 and $0.92 \mu \mathrm{g} / \mathrm{mL}$, respectively) and human breast cancer (MCF-7, $I_{50}=0.65$ and 0.54 $\mu \mathrm{g} / \mathrm{mL}$, respectively), but they were not cytotoxic against human lung cancer (Lu-1). By contrast, CLM and compounds $A$ and $B$ induced relatively less toxicity in normal rat glioma cells (ASK, $I_{50}$ $=11.6 \mu \mathrm{g} / \mathrm{mL}$ ) and human embryonic kidney cells (HEK293, $\left.\mathrm{IC}_{50}=6.74 \mu \mathrm{g} / \mathrm{mL}\right)$, which served as normal cell lines in the current study.

Free radicals are chemical compounds with unpaired electrons; they are formed either endogenously (as a waste product of nutrient metabolism) or exogenously (tobacco smoking, ionising radiation, air pollution, organic solvents and pesticides). An excessive amount of these reactive oxygen species (ROS) is harmful to the body because these agents have the potential to cause tissue injury and even cell death [16]. The damage caused by free radicals may lead to 
many chronic diseases, such as cardiovascular disorders, neural disorders, mild cognitive impairments, Parkinson's and Alzheimer's disease, ulcerative colitis, aging, atherosclerosis and cancer [17]. Medicinal plants are important sources of antioxidant compounds; these natural antioxidants reduce the risk of many chronic diseases [18]. The antioxidative effects of phytoconstituents are mainly due to their redox properties which play an important role in neutralisation of free radicals, quenching of singlet and triplet oxygen species and/or decomposition of peroxides [19]. It is known that the antioxidant effect of a compound is proportional to its number of hydroxyl groups [20]. In the current study, 2,3,8-tri-Omethylellagic acid, 3-O-methylellagic acid 4-O- $\beta$ D-glucopyranoside and the CLM showed significant antioxidant properties, which are probably due to the high number of hydroxyl groups they contain.

\section{CONCLUSION}

The investigation of a methanol extract of Pakistani C. lancifolius (aerial part) yielded two compounds: 2,3,8-tri-O-methylellagic acid and 3O-methylellagic acid 4-O- $\beta$-D-glucopyranoside. These compounds show promising anticancer and antioxidant potentials, which is in agreement with previous studies. The phytochemical and pharmacological potential of $C$. lancifolius have not yet been completely explored; however, the findings of this study are a confirmation of the plant's chemical constituents, biotic properties and potential application as previously reported.

\section{DECLARATIONS}

\section{Acknowledgement}

The work was supported by Government College University, Faisalabad and BZ University Multan, Pakistan. We also acknowledge the technical support of HEJ Research Institute of Chemistry, International Center for Chemical \& Biological Sciences (ICCBS), University of Karachi-75270, Karachi, Pakistan.

\section{Conflict of interest}

No conflict of interest is associated with this work.

\section{Contribution of authors}

We declare that this work was done by the authors named in this article and all liabilities pertaining to claims relating to the content of this article will be borne by the authors.

\section{Open Access}

This is an Open Access article that uses a funding model which does not charge readers or their institutions for access and distributed under the terms of the Creative Commons Attribution License (http://creativecommons.org/licenses/by/ 4.0) and the Budapest Open Access Initiative (http://www.budapestopenaccessinitiative.org/rea d), which permit unrestricted use, distribution, and reproduction in any medium, provided the original work is properly credited.

\section{REFERENCES}

1. Al-Surrayai T, Yateem A, AL-Kandari R. The Use of Conocarpus lancifolius Trees for the Remediation of OilContaminated Soils. Soil Sediment Contam. 2009; 18: 354-368.

2. Hameed ES, Bazaid SA, Shohayeb MM, El-Sayed MM, El-Wakil EA. Phytochemical studies and evaluation of antioxidant, anticancer and antimicrobial properties of Conocarpus erectus L. growing in Taif, Saudi Arabia. Eur J Med Plants 2012; 2: 93-112.

3. Baroon Z, Razzaque MA. Nutritional Evaluation and Palatability Trial of Ensiled Conocarpus Greenery Residues. Exper Agri 2012; 48: 138-147.

4. Redha A, Al-Mansour N, Suleman P, Afzal M, Al- Hasan R. Leaf Traits and Histochemistry of Trichomes of Conocarpus lancifolius a Combretaceae in Semi-Arid Conditions. Am J Plant Sci 2011; 2: 165-174.

5. Saadullah M, Chaudary BA, Uzair M. Antidiabetic potential of Conocarpus lancifolius, Bangladesh $J$ Pharmacol 2014; 9: 244-249.

6. Al-Musayeib N, Mothana RA, Al-Massarani S. Study of the in Vitro Antiplasmodial, Antileishmanial and Antitrypanosomal Activities of Medicinal Plants from Saudi Arabia. Molecules 2012; 17: 11379-11390.

7. Hayssam MA, Mohamed ZMS, Abdel-Megeed A. In-vitro Antibacterial Activities of Alkaloids Extract from Leaves of Conocarpus lancifolius. Engl J Pure Appl Microbiol 2013; 7: 1903-1907.

8. Saadullah M, Chaudary BA, Uzair M. Antioxidant, Phytotoxic and Antiurease Activities, and Total Phenolic and Flavonoid Contents of Conocarpus lancifolius (Combretaceae). Trop J Pharm Res 2016; 15 (3): 555561

9. Vichai V, Kirtikara K. Sulforhodamine B colorimetric assay for cytotoxicity screening Nature protocols 2006; 1 (3): 1112-1116.

10. Thadhani VM, Choudhary MI, Ali S, Omar I, Siddique H, Karunaratne V. Antioxidant activity of some lichen metabolites. Nat Prod Res 2011; 25: 1827-1837.

11. Garrat DC. The Quantitative analysis of Drugs. Chapman and Hall Ltd., Japan, 1964; 3: 456-458.

Trop J Pharm Res, May 2020; 19(5): 1079 
12. George IN, Zhao Y. Pharmacological activities of 2,3,8Tri-O-methyl ellagic acid isolated from the stem bark of Irvingia gabonensis. Afri J Biotechnol 2007; 6(16): 19101916.

13. Khallouki F, Haubner R, Hull WC, Erben G, Spiegelhalder $B$, Bartsch $H$, Owen RW. Isolation, purification and identification of ellagic acid derivatives, catechins, and procyanidins from the root bark of Anisophyllea dichostyla R. Br. F Food and Chemical Toxicol 2007; 45: 472-485.

14. Olano C, Méndez C, Salas J. Antitumor compounds from marine actinomycetes. Marine drugs 2009; 7(2): 210248.

15. Greenwell M, Rahman P. Medicinal plants: their use in anticancer treatment. Int J Pharm Sci Res 2015; 6(10): 4103.
16. Chanda S, Dave R. In vitro models for antioxidant activity evaluation and some medicinal plants possessing antioxidant properties: An overview. Afri J Microbiol Res 2009; 3(13): 981-996.

17. Alam MN, Bristi NJ. Rafiquz zaman M. Review on in vivo and in vitro methods evaluation of antioxidant activity. Saudi Pharml J 2013; 21(2): 143-152.

18. Chanda S, Dave R. Kaneria M. In vitro antioxidant property of some Indian medicinal plants. Res $\mathrm{J}$ Med Plant 2011; 5(2): 169-179.

19. Pietta $P$, Sionetti $P$, Mauri P. Antioxidant activity of selected medicinal plants. J Agric Food Chem 1998; 46 : 4487-90.

20. Simic A, Manojlovic $D$, Segan $D$, Todorovic $M$. Electrochemical behavior and antioxidant and prooxidant activity of natural phenolics. Molecul 2007; 12: $2327-40$. 